\title{
Detection of Methylobacterium radiotolerans IMBG290 in potato plants by in situ hybridization
}

\author{
O. V. Podolich, L. P. Ovcharenko' ${ }^{1}$ N. O. Kozyrovska' ${ }^{1}$ A. M. Pirttila ${ }^{2}$
}

Institute of Agroecology of UAAS

12 Metrologichna str., Kyiv, Ukraine, 03680

${ }^{1}$ Institute of Molecular Biology and Genetics of National Academy of Sciences of Ukraine

150 Acad. Zabolotnoho str., Kyiv, Ukraine, 03680

${ }^{2}$ Department of Biology University of Oulu

Linnanmaa, PO Box 3000, FIN-90014 Oulu, Finland

kozyr@imbg.org.ua

\begin{abstract}
A new bacterial strain of pink-pigmented facultative methylotroph (M. radiotolerans IMBG290) which was previously isolated from in vitro grown potato plantlets after their inoculation with Pseudomonas fluorescens IMBG163 was detected in tissues by in situ hybridization method (ISH/FISH). The presence of Methylobacterium rRNA was observed in leaves and stems of potato plantlets, whereas no signal was detected in potato roots. The signal was less abundant in the untreated plants than in the plantlets infected with $M$. radiotolerans $I M B G 290$.
\end{abstract}

Keywords: in situ hybridization, Methylobacterium radiotolerans IMBG290, potato plantlets.

Introduction. The pink-pigmented facultative methylotrophic bacteria (PPFMB) are indispensable inhabitants of the phyllosphere where methanol is produced [1]. Under natural conditions, colonization of plant leaves by PPFMB seems to occur via soil particle transfer to the leaves by air [2]. Bacteria in the genus Methylobacterium are often isolated from buds, roots and in vitro plant cultures, and they are also known as endophytic bacteria, found inside plant tissue [3-8]. These bacteria evidently have an intimate association with plants, as they promote plant growth and development by production of phytohormones [2, 9-13]. The genus Methylobacterium belongs to $\alpha$ Proteobacteria, and members of this genus are capable of growing on monocarbon compounds such as

(c) Інститут молекулярної біології і генетики НАН України, 2009 methanol and methylamine, as well as on a wide range of multicarbon substrates [3]. Associated with their carbon utilitization capabilities, methylotrophic bacteria can be efficient destructors of organic pollutants in the environment $[14,15]$.

Endophytic community of potato plants varies, and it is composed by a broad phylogenetic spectrum of bacteria: $\alpha-, \beta$-, and $\gamma$-Proteobacteria, FlexibacterCytophaga-Bacteroides, gram-positive microorganisms with high $\mathrm{G}+\mathrm{C}$-content, and Planctomycetales [16-18]. Bacteria of the genus Methylobacterium have not earlier been detected inside the potato in vitro tissue. In our experiments PPFMB have been detected in potato plantlet bacterial communities after activating them with exogenic bacterium [19].

Here we describe localization of a bacterial isolate capable of utilizing methanol as a source of carbon and 
energy in tissues of both uninoculated and inoculated in vitro-grown potato plants.

Materials and Methods. Potato plantlets. Potato (Solanum tuberosum L.) cultivar Chervona Ruta variety of potato was used in this study. In vitro-grown potato plantlets were grown on Murashige and Skoog medium (MS) [20] without phytohormones for one and a half year, in a conditioned room under a light-dark period of $16 / 8 \mathrm{~h}$ at $24{ }^{\circ} \mathrm{C}$ and $150 \mu \mathrm{E} \mathrm{m}^{-2} \mathrm{~s}^{-1}$.

Bacterial strains and culture conditions. PPFMB isolate was cultured in M9 medium [21] supplemented with methanol $(1.0 \%)$ at $28{ }^{\circ} \mathrm{C}$ for $3-4$ days.

Inoculation of potato plants. Nodal cuttings of six-week-old potato plantlets were used for inoculation with the PPFMB isolate. The methylobacteria culture was pelleted by centrifugation $(3000 \mathrm{~g}, 10 \mathrm{~min})$, rinsed, and resuspended in sterile distilled water (SDW) to a concentration of $10^{8} \mathrm{CFU} / \mathrm{ml}^{-1}$. The plantlets were cut in 1-cm pieces and incubated with bacterial suspension for $5 \mathrm{~min}$. The cuttings were dried on a sterile paper and placed on the MS medium without hormones. Untreated plants were incubated in SDW instead of the bacterial culture.

In situ hybridization. Samples of stems, leaves, and roots of plantlets were taken for in situ hybridization experiments. Both PPFMB-infected and untreated plants were analyzed. All samples were surfacesterilized for $1 \mathrm{~min}$ in $70 \%$ ethanol and for $15 \mathrm{~min}$ in $6 \%$ calcium hypochlorite, followed by rinsing three times in SDW. The leaf tissues were cut in pieces of $1.5 \times 1.5 \mathrm{~mm}$, stems were cut in $1 \mathrm{~mm}^{2}$ - and roots in $1 \mathrm{~mm}^{2}$-pieces. The cuttings were fixed in $2 \%$ paraformaldehyde, 2,5\% glutaraldehyde, $0.1 \mathrm{M}$ saline buffer, $\mathrm{pH} 7.4$, at $4{ }^{\circ} \mathrm{C}$ under vacuum overnight. The fixed samples were dehydrated, cleared through ethanol/t-butanol series and embedded in paraffin. Oligonucleotide probes $\mathrm{MB}$ and E11 [5] complementary to the unique regions of $16 \mathrm{~S}$ rRNA of $\mathrm{Me}$ thylobacterium and eubacteria, respectively, were used for in situ hybridization. The oligonucleotides were end-labeled with fluorescein during synthesis or with digoxigenin, using the DIG Oligonucleotide 3'-end Labeling Kit («Roche Applied Science», Finland).

Hybridization was performed as described by Pirttila et al. [5]. The paraffin-embedded specimens were sectioned, and the $8 \mu \mathrm{m}$ sections were baked on silane-coated slides. The paraffin was removed in xylene prior to hybridization. All samples of stems, roots and leaves of infected and untreated potato in vitro plants were hybridized with the probes MB or E11 as described by Pirttila et al. [5].

The detection of the digoxigenin label was performed with the DIG Nucleic Acid Detection Kit («Roche Applied Science»), and the slides were viewed with optical microscope (Optiphot-2 Photomicroscope, «Nikon», Japan) under bright field illumination. For the fluorescein label, the samples were viewed under fluorescent light with fluor objectives, episcopic-fluorescence attachment EF-D, and the filter set UV-1A («Nikon»).

DNA staining. The RNase-treated sections were stained with ethidium bromide $(10 \mu \mathrm{g} / \mathrm{ml})$ for $45 \mathrm{~min}$ in the dark. The slides were rinsed with SDW, air dried in the dark and viewed immediately under the fluorescent light.

Bacterial DNA isolation, PCR and sequencing. Bacterial DNA isolation was performed with UltraClean $^{\mathrm{TM}}$ Microbial DNA isolation kit (MoBio Laboratories Inc., USA). To determine the nucleotide sequence of the rrs gene (16S ribosomal RNA) a PCR product was amplified with primers $\mathrm{pA}$ and $\mathrm{pH}$ described by Edwards et al. [22], cleaned with UltraClean $^{\mathrm{TM}}$ PCR Clean-up DNA purification kit (MoBio Laboratories Inc., USA) and cloned into vector $p T Z 57 R / T$ using InsTAclone ${ }^{\mathrm{TM}}$ PCR Cloning Kit («Fermentas», Lithuania). The PCR product was then sequenced with primers M13/pUC (forward and reverse) («Fermentas») by the Sanger method [23] using «Amersham» (USA) sequencing kit Cy5 AutoCycle and apparatus ALF express («Pharmacia Biotech.», Sweden). The nucleotide sequence was analyzed with the basic local alignment search tool (BLAST) and Vector NTI 8.0 program (Infomax Inc., USA).

Nucleotide sequence accession number. The sequence generated in this study has been deposited in the GenBank database under accession number EF583689.

Results. The endophytic isolate M1, originated from in vitro-grown potato [19], was characterized by sequencing the $16 \mathrm{~S}$ rDNA, and a comparison of specific sequence of the rrs gene with sequences 
deposited to GenBank suggested that the M1 isolate belongs to methylotrophic bacteria, having the highest homology to $M$. radiotolerans $(96-100 \%)$ and M. organophilum (90\%). A detailed analysis of the sequence demonstrated that the region conserved between methylobacteria was present and a variable region of $50 \mathrm{bp}$ (nucleotides 901-951) was identical to $M$. radiotolerans. The sequence was $99 \%$ identical and had a seqmatch score of 0.933 with type strains of M. radiotolerans (JCM 2831, DSM 1819) in RDP (Ribosomal DNA Project).

In situ hybridization was performed on tissues of leaves, stems and roots of in vitro-grown potato plants. The specific for bacteria in the Methylobacterium genus probe $\mathrm{MB}$ was used for hybridization. Both untreated and $M$. radiotolerans-inoculated plants were surface-disinfected prior a processing for hybridization in order to avoid epiphyte contamination of the samples.

The hybridization signals of Methylobacterium rRNA were detected in leaves of untreated plants mainly at the tip of the leaf in sponge and palisade parenchyma and xylem vessels (Fig. 1, $A-D$, see inset). In the infected leaf tissues, the signals were present in the xylem vessels (Fig. 1, E-G) and in parenchyma tissues (Fig. 1, E). In the stems of infected and untreated plants the Methylobacterium rRNA was mainly detected in the parenchyma and the vascular tissues (Fig. 2, $A-C$, see inset). In the untreated plants the signal was weaker than in infected plants (Fig. 2, $D)$. DNA staining of infected stem samples was observed in areas indicated by in situ hybridization, supporting the presence of bacteria in the genus Methylobacterium inside cells of parenchyma tissues (Fig. 2, B). Specifically, in the stem parenchyma both types of hybridization signals and the DNA staining revealed biofilms (Fig. 2, A-D). Based on the signals bacteria were found at highly localized areas in the biofilm (Fig. 2, $A-C$ ). In the root of the infected plants, Methylobacterium rRNA was detected in vascular (Fig. $3, A$, see inset) and parenchyma tissues. In the untreated plants Methylobacterium rRNA was not detected in the root tissues (Fig. 3, B).

Discussion. Methylobacteria have earlier been found as endophytes in plant tissues $[5,6,24]$ but the locations, infection processes and roles of these bacteria have rarely been studied. The methylotrophs are suspected to supply the plant with growth stimulating compounds or to help the plant in activation of defense system for a better adaptation to the environment. The results of the in situ hybridization experiment showed the presence of Methylobacterium rRNA in all organs (leaves, stems and roots) of the inoculated potato plants. Our results provide the first direct evidence that methylotrophs exist inside in vitro potato tissues. These bacteria may exist as regular inhabitants of potato plants since we found bacteria in plantlets after in vitro cultivation of one and half year. In the untreated plants, the Methylobacterium rRNA was detected only in the leaves and stems. It means that methylobacteria preferably reside in the aerial parts of these plants. This is also supported by the fact that the hybridization signal was the most abundant in the stems, slightly less in the leaves and the lowest in the root tissues of Methylobacterium-inoculated potato plantlets.

Since these bacteria were detected by molecular method and could not be isolated on selective media, they may normally exist in an unculturable state inside the potato plants. Methylobacteria can persist in natural environments by forming biofilms [25]. Biofilms are specifically often found on plant surfaces and provide a mechanism for the bacteria to survive in harsh environments [26]. Biofilms are also an unculturable state of the bacteria. In the in situ hybridization experiments, a distinct biofilm structure was detected in the stem parenchyma of the in vitro-grown potato plants. Therefore, a regular existence as biofilms inside the potato tissues may explain the lack of culturability of these bacteria.

Intercellular spaces and xylem vessels are the most commonly reported locations of endophytic bacteria [27-31]. In the present study the Methylobacteriumspecific in situ hybridization signals were mainly located in the xylem vessels of leaves and stems, but not in the root vessels of untreated potato plants. This is in agreement with the data of absence of Serratia marcescens rice root interior [30], as well as the endophyte Enterobacter asburiae in cotton roots [32]. The bacterial endophytes spread systemically but not in root inner tissue after seed inoculation. In our study the absence of the methylobacteria in roots of untreated 
potato plants may be explained by the putative role of these bacteria in scavenging monocarbon wastes within the leaf parenchyma tissues where these compounds are produced in a larger scale.

In general, it is considered that some bacterial endophytes do not inhabit living vegetative cells [29, 30, 33]. However, immunogold labeling allowed the precise location of endophyte E. asburiae within epidermal cells [32] and intact root cortical cells of cotton [34]. Using the in situ hybridization method, Pirttila and co-authors detected species in the genus Methylobacterium in the meristem cells of Scots pine buds [5]. In this study we observed bacterial rRNA hybridization signals inside cells of stem parenchyma of in vitro-grown potato plants inoculated with $M$. radiotolerans IMBG290. However, the cells appeared to be senescing, and this may explain the bacterial presence in these cells.

\section{О. В. Подоліч, Л. П. Овчаренко, Н. О. Козировська, А. М. Пірттіла}

Визначення локалізації Methylobacterium radiotolerans IMBG290 у тканинах картоплі методом гібридизації in situ

Резюме

Новий штам рожево-пігментованої факультативноӥ метилотрофної бактерії M. radiotolerans IMBG290, виділений раніше з культури тканин картоплі після обробки бактерією Pseudomonas fluorescens IMBG163, визначено в тканинах картоплі методом гібридизації іп situ (ISH/FISH). Наявність рибосомної $16 S$ РНК спостерігали в листі та стеблах пробіркових рослин, проте ї̈ не знайдено в корінні картоплі. У рослин, оброблених M. radiotolerans IMBG290, гібридизачійний сигнал виявився сильнішим, ніж у контрольних (необроблених) рослин.

Ключові слова: гібридизаџія in situ, Methylobacterium radiotolerans IMBG290, живиі картоплі.

О. В. Подолич, Л. П. Овчаренко, Н. А. Козыровская, А. М. Пирттила

Определение локализации Methylobacterium radiotolerans IMBG290 в растениях картофеля методом гибридизации in situ

Резюме

Новый штамм розово-пигментированной факультативной метилотрофной бактерии M. radiotolerans IMBG290, выделенный ранее из культуры тканей картофеля после обработки бактерией Pseudomonas fluorescens IMBG163, определен в тканях картофеля методом гибридизачии in situ (ISH/FISH). Присутствие $16 \mathrm{~S}$ рРНК M. radiotolerans наблюдали в листьях и стеблях, но не в корнях картофеля. У растений, обработаннblx M. radiotolerans IMBG290, гибризационный сигнал был сильнее, чем у контрольных (необработанных) растений.
Ключевые слова: гибридизация in situ, Methylobacterium radiotolerans IMBG290, черенки картофеля.

\section{REFERENCES}

1. Corpe $W$. A. A method for detecting methylotrophic bacteria on solid surfaces // J. Microbiol. Meth.-1985.-3, N 1.P. 215-221.

2. Romanovskaya V. A., Stolyar S. M., Malashenko Y. R., Dodatko T. N. The ways of plant colonization by Methylobacterium strains and properties of these bacteria // Microbiology.2001.-70, N 1.-P. 221-227.

3. Corpe W. A., Basil D. V. Methanol-utilizing bacteria, associated with green plants // Develop. Indust. Microbiol.1982.-23, N 2.-P. 483-493.

4. Wilson M., Hirano S. S., Lindow S. E. Location and survival of leaf-associated bacteria in relation to pathogenicity and potential for growth within the leaf // Appl. Environ. Microbiol.-1999.-65, N 4.-P. 1435-1443.

5. Pirttila A. M., Laukkanen H., Pospiech H., Myllyla R., Hohtola $A$. Detection of intracellular bacteria in the buds of Scotch pine (Pinus sylvestris L.) by in situ hybridization // Appl. Environ. Microbiol.-2000.-66, N 7.-P. 3073-3077.

6. Pirttila A. M., Pospiech H., Laukkanen H., Myllyla R., Hohtola $A$. Seasonal variations in location and population structure of endophytes in buds of Scots pine // Tree Physiol.2005.-25, N 3.-P. 289-297.

7. Sy A., Giraud E., Jourand P., Garcia N., Willems A., de Lajudie P., Prin Y., Neyra M., Gillis M., Boivin-Masson C., Dreyfus $B$. Methylotrophic Methylobacterium bacteria nodulate and fix nitrogen in symbiosis with legumes // J. Bacteriol.2001.-183, N 1.-P. 214-220.

8. Idris R., Trifonova R., Puschenreiter M., Wenzel W., Sessitsch $A$. Bacterial communities associated with flowering plants of the Ni hyperaccumulator Thlaspi goesingense // Appl. Environ. Microbiol.-2004.-70, N 5.-P. 2667-2677.

9. Ivanova E. G., Doronina N. V., Shepelyakovskaya O., Laman A. G., Brovko E. A., Trotsenko Y. A. Facultative and obligate aerobic methylobacteria synthesize cytokinins // Mikrobiologiya.-2000.-69, N 3.-P. 764-769.

10. Ivanova E. G., Doronina N. V., Trotsenko Y. A. Aerobic methylobacteria are capable of synthesizing auxins // Microbiologiya.-2001.-70, N 2.-P. 392-397.

11. Araujo W. L., Marcon J., Maccheroni W. Jr., Van Elsas J. D., Van Vuurde J. W., Azevedo J. L. Diversity of endophytic bacterial populations and their interaction with Xylella fastidiosa in citrus plants // Appl. Environ. Microbiol.2002.-68, N 10.-P. 4906-4914.

12. Madhaiyan M., Poonguzhali S., Senthilkumar M., Seshadri S., Chung H., Yang J., Sundaram S., Tongmin S. A. Growth promotion and induction of systemic resistance in rice cultivar Co-47 (Oryza sativa L.) by Methylobacterium spp. // Bot. Bull. Acad. Sin.-2004.-45, N 2.-P. 315-324.

13. Maliti C. M., Basile D. V., Corpe W. A. Effects of Methylobacterium spp. strains on rice Oryza sativa L. callus induction, plantlet regeneration, and seedlings growth in vitro // J. Torrey Bot. Soc.-2005.-132, N 2.-P. 355-327.

14. Kayser M. F., Ucurum Z., Vuilleumier S. Dichloromethane metabolism and C-1 utilization genes in Methylobacterium strains // Microbiology.-2002.-148, N 6.-P. 1915-1922.

15. Van Aken B., Yoon J. M., Schnoor J. L. Biodegradation of nitro-substituted explosives 2,4,6-trinitrotoluene, hexahydro-1, 
3,5-trinitro-1,3,5-triazine, and octahydro-1,3,5,7-tetranitro1,3,5-tetrazocine by a phytosymbiotic Methylobacterium sp. associated with poplar tissues (Populus deltoides $\times$ nigra DN34) // Appl. Environ. Microbiol.-2004.-70, N 1.-P. 508517.

16. Garbeva P., Overbeek L. S., Vuurde J. W., Elsas J. D. Analysis of endophytic bacterial communities of potato by plating and denaturing gradient gel electrophoresis (DGGE) of $16 \mathrm{~S}$ rDNA based PCR fragments // Microbiol. Ecol.2001.-41, N 2.-P. 369-383.

17. Krechel A., Faupel A., Hallmann J., Ulrich A., Berg G. Potato-associated bacteria and their antagonistic potential towards plant-pathogenic fungi and the plant-parasitic nematode Meloidogyne incognita (Kofoid \& White) Chitwood // Can. J. Microbiol.-2002.-48, N 3.-P. 772-786.

18. Sessitsch A., Reiter B., Berg G. Endophytic bacterial communities of field-grown potato plants and their plantgrowth-promoting and antagonistic abilities // Can. J. Microbiol.-2004.-50, N 1.-P. 239-249.

19. Podolich O. V., Ardanov P. E., Voznyuk T. M., Kovalchuk M. V., Danylchenko O. O., Laschevskyi V. V., Lyastchenko S. A., Kozyrovska $N$. O. Endophytic bacteria from potato in vitro activated by exogenic non-pathogenic bacteria // Biopolymers and Cell.-2007.-23, N 1.-P. 21-27.

20. Murashige T., Skoog E. A revised medium for rapid growth and bioassays with tobacco tissue cultures // Physiol. Plant.1962.-15, N 2.-P. 473-497.

21. Miller J. H. Experiments in molecular genetics.-New York: Cold Spring Harbor Lab. publ., 1972.-436 p.

22. Edwards U., Rogal T., Bloecker M., Boettger E. C. Isolation and direct complete nucleotide determination of entire genes. Characterization of a gene coding for $16 \mathrm{~S}$ ribosomal RNA // Nucl. Acid Res.-1989.-17, N 19.-P. 7843-7853.

23. Sanger F., Nicken S., Coulson A. R. DNA sequencing with chain-terminating inhibitors // Proc. Nat. Acad. Sci. USA.1977.-74, N .-P. 5463-5467.

24. Leifert C., Morris C. E., Waites W. M. Ecology of microbial saprophytes and pathogens in tissues culture and field grown plants: reasons for contamination problem in vitro // Crit. Rev. Plant Sci.-1994.-3.-P. 139-183.
25. Kelley S. T., Theisen U., Angenent L. T., Amand A., Pace N. $R$. Molecular analysis of shower curtain biofilm microbes // Appl. Environ. Microbiol.-2004.-70, N 7.-P. 4187-4192.

26. Morris C. E., Monier J. M., Jacques M. A. Methods for observing microbial biofilms directly on leaf surfaces and recovering them for isolation of culturable microorganisms // Appl. Environ. Microbiol.-1997.-63, N 4.-P. 1570-1576.

27. Reinhold-Hurek B., Hurek T., Fendrik I. Cross-reaction of predominant nitrogen-fixing bacteria with enveloped, round bodies in the root interior of kallar grass // Appl. Environ. Microbiol.-1987.-53, N 4.-P. 889-891.

28. Nguyen T., Ton T., Tarasenko V., Kozyrovska N. Nitrogenfixing bacteria colonize xylem of rice root// Biopolymers and Cell.-1989.-5, N 2.-P. 97-99 (Rus.).

29. James E. K., Olivares F. B. Infection and colonization of sugar cane and other graminaceous plants by endophytic diazotrophs // Crit. Rev. Plant Sci.-1997.-17.-P. 77-119.

30. Gyaneshwar P., James E. K., Mathan N., Reddy P. M., Reinhold-Hurek B., Ladha J. K. Endophytic colonization of rice by a diazotrophic strain of Serratia marcescens // J. Bacteriol.-2001.-183, N 8.-P. 2634-2645.

31. Compant S., Reiter B., Sessitsch A., Nowak J., Clement C., Barka E. A. Endophytic colonization of Vitis vinifera L. by plant growth-promoting bacterium Burkholderia sp. strain PsJN // Appl. Environ. Microbiol.-2005.-71, N 4.-P. 16851693.

32. Quandt-Hallmann A., Kloepper J. W. Immunological detection and localization of the cotton endophyte Enterobacter asburiae JM22 in different plant species // Can. J. Microbiol.-1996.-42, N 6.-P. 1144-1154.

33. Reinhold-Hurek B., Hurek T. Interactions of gramineous plants with Azozrcus spp. and other diazotrophs: Identification, localization and perspectives to study their function // Crit. Rev. Plant Sci.-1998.-17.-P. 29-54.

34. Quadt-Hallmann A., Hallmann J., Kloepper J. W. Bacterial endophytes in cotton: location and interaction with other plant-associated bacteria // Can. J. Microbiol.-1997.-43, N 2.-P. 254-259. 